$11-13-2013$

\title{
Gathering "Wild" Food in the City: Rethinking the Role of Foraging in Urban Ecosystem Planning and Management
}

Rebecca J. McLain

Portland State University

Patrick T. Hurley

Ursinus College,phurley@ursinus.edu

Marla R. Emery

USDA Forest Service

Melissa R. Poe

Northwest Sustainability Institute

Follow this and additional works at: https://digitalcommons.ursinus.edu/environment_fac

Part of the Environmental Studies Commons, Human Geography Commons, Nature and Society $\underline{\text { Relations Commons, Other Political Science Commons, Sustainability Commons, and the Urban }}$ Studies and Planning Commons

Click here to let us know how access to this document benefits you.

\section{Recommended Citation}

McLain, Rebecca J.; Hurley, Patrick T.; Emery, Marla R.; and Poe, Melissa R., "Gathering "Wild" Food in the City: Rethinking the Role of Foraging in Urban Ecosystem Planning and Management" (2013). Environmental Studies Faculty Publications. 5.

https://digitalcommons.ursinus.edu/environment_fac/5 


\title{
Gathering "wild" food in the city: rethinking the role of foraging in urban ecosystem planning and management
}

\author{
Rebecca J. McLain ${ }^{a *}$, Patrick T. Hurley ${ }^{\mathrm{b}}$, Marla R. Emery ${ }^{\mathrm{c}}$ and Melissa R. Poe ${ }^{\mathrm{d}}$ \\ ${ }^{a}$ Institute for Sustainable Solutions, Portland State University, Portland, USA; ${ }^{b}$ Department of \\ Environmental Studies, Ursinus College, Collegeville, USA; ${ }^{c}$ USDA-Forest Service, Northern \\ Research Station, Burlington, USA; ${ }^{d}$ Northwest Sustainability Institute, Seattle, USA
}

(Received 12 February 2013; accepted 30 August 2013)

\begin{abstract}
Recent "green" planning initiatives envision food production, including urban agriculture and livestock production, as desirable elements of sustainable cities. We use an integrated urban political ecology and human-plant geographies framework to explore how foraging for "wild" foods in cities, a subversive practice that challenges prevailing views about the roles of humans in urban green spaces, has potential to also support sustainability goals. Drawing on research from Baltimore, New York City, Philadelphia, and Seattle, we show that foraging is a vibrant and ongoing practice among diverse urban residents in the USA. At the same time, as reflected in regulations, planning practices, and attitudes of conservation practitioners, it is conceptualised as out of place in urban landscapes and an activity to be discouraged. We discuss how paying attention to urban foraging spaces and practices can strengthen green space planning and summarise opportunities for and challenges associated with including foragers and their concerns.
\end{abstract}

Keywords: human-plant geographies; non-timber forest products; sustainability; urban forestry; urban political ecology

\section{Introduction}

On a mild October day, a group of six people gather by the entrance to the Schuylkill bike trail on the outskirts of Valley Forge National Park in Pennsylvania, eager to learn about the edible plants and fungi found along the trail. Several are members of an area "meet-up" devoted to learning about wild foods, but only three have any real long-term experience with collecting wild foods. The others have browsed during hikes, walks, and other recreational outings, but are keen to learn more about foods they can find in this peri-urban setting. Our guide, who is more accustomed to leading tours closer to Center City Philadelphia, introduces us to several edible weeds in the vicinity of the trailhead, including

${ }^{*}$ Corresponding author. Email: mclainrj@pdx.edu

The work of Rebecca McLain, Patrick Hurley, Melissa Poe and Marla Emery is published by permission of the US Forest Service under Contract No. PNW10JV11260489-024; PNW09JV11261975- 056. The U.S. Government retains for itself, and others acting on its behalf, a paid-up, non-exclusive, and irrevocable worldwide license in said article to reproduce, prepare derivative works, distribute copies to the public, and perform publicly and display publicly, by or on behalf of the Government.

The work of Marla Emery was authored as part of their official duties as Employee of the United States Government and is therefore a work of the United States Government. In accordance with 17 U.S.C. 105, no copyright protection is available for such works under U.S. Law. 
common dandelion (Taraxacum spp.), common plantain (Plantago major), blue chicory (Cichorium intybus), and a species of violet (Viola spp.), beginning a tour of wild plants that are known for their edible, medicinal, and, in a few cases, craft or fibre uses. Typical of the region's bike trails, our route through the county park that adjoins the National Park takes us along a historic rail line and power line easements. We move along the forest fragments, wooded fence lines, and open fields characteristic of the urban-suburban countryside in the Philly Metro area. Many of the plants we see (e.g. blackberry (Rubus spp.), stinging nettle (Urtica dioica), common mullein (Verbascum thapsus)) would hardly be thought of as key species of conservation concern but harvesting them is a prohibited activity on county parkland. A few - berries in particular - can be legally harvested just across the river in the National Park. In many ways, the tour represents a direct challenge to the governing management regime of the area's public parks. At a time when urban foraging is growing in recognition within the popular media, one might ask what this tour and this group's activities reveal about a practice that is often thought of as belonging to far-flung rural places? Moreover, in what ways does this tour open our eyes to an increasingly more visible, if not more common, activity in the city?

Bringing nature back into cities and reconnecting urbanites with that nature are frequently cited in the urban green space planning literature as essential to fostering sustainable urban ecosystems (Erickson 2006, Beatley 2011). At the same time, in a process that Gobster has referred to as the "museumification" of nature (2007), urban conservation programmes typically favour a discursive and regulatory construction of urban nature as a provider of ecological services and intangible values rather than a source of products for human use (Williams 1973, Moore 2006). Parks have become museumified landscapes which humans can look at, recreate in, and pass through, but where harvesting is strongly discouraged. Cronon's (2000, p. 675) counsel to view humans as integral to urban nature and "an essential and irreversible feature of the history that has produced the systems we seek to understand, protect, and use" suggests it may be desirable to thoughtfully (re)incorporate materially productive relationships between people and nature in urban green space planning. To do so is to recognise that urban green spaces already serve as provisioning sites where people collect plants and fungi - often surreptitiously and in defiance of rules prohibiting such activities - for a variety of uses.

Urban agriculture scholarship has provided an opening for broader acceptance of urban green space as a source of products for human use (Nordahl 2009, Certomà 2011, Metcalf and Widener 2011, Turner 2011). In addition, a small but provocative literature on urban fisheries (e.g. Westphal et al. 2008) points to other places and instances where natural resources are harvested in the city. However, the harvesting of non-timber forest products (NTFPs) in urban areas remains largely unexamined in the scholarly literature (McLain et al. 2012b). Yet recent popular literature (Severson 2009, Craft 2010, Foderaro 2011) depicts foraging for food and other products as a still-existing or re-emergent practice, in which city residents interact with diverse urban landscapes and vegetation, often finding edible, medicinal, and craft-related species in formally and informally managed spaces where ownership may be less than clear. This literature, along with a small body of scientific research (Jahnige 2002, Gabriel 2006, Grabbatin et al. 2011, McLain et al. 2012b, Hurley et al. 2013, Poe et al. 2013), suggests that foraging does occur in cities, suburbs, and peri-urban areas, often as a subversive practice in parks and other green spaces or in interstitial spaces such as planting strips, alleyways, and along railroad tracks.

Previous research defines NTFPs in the urban context as any plant, plant material, or fungus collected from urban street trees, yards, vacant lots, and landscaped areas, as well as formal parks both large and small (Jahnige 2002). We note that urban NTFP species 
include wild plants and fungi (i.e. species not altered through horticultural techniques or genetic engineering), "feral" plants (cultivars that spread or persist without human intervention), and the fruits or other desired parts of domesticates where these are incidental to the primary reason for which the specimen was planted. Urban NTFPs include native and nonnative species, as well as invasive and non-invasive species. We refer to people who collect NTFPs in and around cities as urban foragers.

Urban and peri-urban landscapes are known to support foraging. For example, AfricanAmerican basket-makers in the greater Charleston, South Carolina area, have maintained longstanding natural-resource-based livelihoods through harvesting strategies that make use of newly organised access arrangements that subvert traditional landscape meanings (e.g. entranceways to subdivisions, commercial shopping areas, and roadside and median beautification strips as harvest sites) as well as through non-sanctioned gathering in socalled fringe ecologies (Hurley et al. 2013). Likewise, previous research on urban NTFPs points to the ways that foraging may challenge existing management philosophies, through non-sanctioned harvests in parks, as well as highlighting the importance to harvesters of roadside vegetation and weedy species in ruderal ${ }^{1}$ landscapes such as alleyways, street planters, and other public rights of way (Jahnige 2002, Gabriel 2006, Grabbatin et al. 2011). The productive use of urban plants appears to be characterised by diverse and changing access strategies, in which foragers seek formal, informal, and nonsanctioned modes of access to the plant species on which they rely.

We argue that foraging deserves to be considered a legitimate and potentially positive practice in urban ecosystems, drawing on evidence from an extensive review of the literature on human-urban nature interactions (McLain et al. 2012a) and findings from exploratory urban foraging studies in four US cities. We begin by considering how nature was historically represented in the science and practice of urban green space planning, paying close attention to the ways its normative assumptions erase urban nature as a provider of natural resources for individual or household consumption. We note how recent changes in understandings of the nature of urban nature open the possibilities for recognition of urban foraging as acceptable. To help conceptualise urban foraging, we review the work of geographers who examine urban nature in terms of relationships between human and non-human actors. We then summarise findings from exploratory research on contemporary foraging practices in Baltimore, New York, Philadelphia, and Seattle. We do not provide a rigorous comparative analysis of these cases, which differed substantially in their data collection methods. Rather, we use these studies to demonstrate that foraging is an ongoing and well-established practice in US cities, to identify the spaces where foraging takes place and to articulate key concerns of managers and harvesters. We discuss how paying attention to the spaces and practices of urban foraging can strengthen urban green space planning. Finally, we summarise opportunities for and challenges associated with including foragers and their concerns in urban green space planning.

\section{Urban green space planning}

The belief that green space is an important aspect of cities is not new to twenty-first century urban planning. In the USA, influential landscape architects of the nineteenth and early twentieth century, such as Frederick Law Olmsted and his student Charles Eliot, advocated the creation of networks of urban parks connected to each other and, through river corridors, to green spaces beyond the boundaries of urban settlements (Gobster 2007). These planners argued that public spaces with large amounts of vegetation were essential elements of healthy, functional cities (Botkin and Beveridge 1997). Attractive urban green spaces, 
they contended, would serve as playgrounds, as well as places for relaxation and spiritual rejuvenation, which would ensure the development of a physically fit and emotionally stable urban populace. Many US cities implemented park systems designed or inspired by Olmsted, his colleagues, or their students during the early twentieth century, which served as building blocks for creating more extensive and intricate greenway systems within and between cities in the late twentieth century (Fábos 2004).

Conceptualised as antidotes to the demands of labour in offices and factories, parks were designed as aesthetic backdrops for activities such as sitting, walking, birdwatching, and playing (Gobster 2007). These new landscapes emphasised aesthetics, relaxation, recreation, and refuge, reinforcing emerging notions about which human-nature interactions belonged in the city and which in the country. In tandem with efforts to create more sanitary cities (Pincetl 2010), productive practices were defined as rural and, therefore, inappropriate inside the city and city parks (Moore 2006, Gobster 2007). Thus, cities such as Columbus, Ohio materially and discursively erased subsistence gardening (Moore 2006) and rules prohibiting foraging in parks became commonplace (McLain et al. 2012b). Further, development and maintenance of the great urban parks demanded centralisation and professionalisation of their care. Decision-making powers and management authority were vested in municipal governments and professional park managers. Technocratic green space planning and management emerged with citizens viewed as users, rather than stewards or active co-producers of nature.

With the popularisation of the concept of sustainable development in the late 1980s, planners began to experiment with green space policies that explicitly seek to integrate social, economic, and ecological concerns in urban environments. Concurrently, notions of the biophysical nature of urban environments have changed, informed by the field of urban ecology. Parks, nature reserves, and connecting greenways continue to form the core of most green infrastructure designs (Benedict and McMahon 2006). More recently, Pincetl and Gearin (2005) have pointed to the importance of recognising and incorporating "interstitial, raw, or 'feral' lands ..." into park creation and protection. They note that such places, including the street trees and other vegetation that characterise these spaces, are important for meeting the community and ecosystem needs of urban neighbourhoods that do not have large expanses of undeveloped land or existing parks. Feral lands and vacant lots, as well as the ruderal landscapes described by Del Tredici (2010), harbour diverse species and plant communities, even if this diversity is not well recognised or appreciated by ecological scientists or planners. The "fringe ecologies" created by suburbanisation and identified by Hurley et al. (2008) as important gathering sites for sweetgrass basketry materials are another important type of interstitial space. Moreover, the concept of fringe ecologies provides a pathway for thinking about formal and informal vegetation dynamics at the fringe or perimeter of new residential or commercial developments, dynamics that may make access and gathering possible in landscapes increasingly characterised by private property and suburban land management dynamics.

Melding conservation with sustainable development, contemporary urban green space planning conceptualises human and natural systems as inextricably linked. Moreover, community involvement is now considered fundamental to green space planning (Kambites and Owen 2006) and linkages between civil society and governmental institutions are viewed as requisite for sustainable policies and management practices (Pincetl 2010). This approach to urban green spaces brings with it the advantages of better targeting public resources, community buy-in, and access to valuable local knowledge (Kambites and Owen 2006).

These shifts in the conceptualisation of urban nature and human roles in it have, to some extent, created openings for the return of productive practices such as farming, horticulture, 
and bee-keeping to public green spaces (Lovell 2010). However, urban foraging has received little attention in either urban green space planning or its associated scholarly literature (McLain et al. 2012a, 2012b). A notable exception is Nordahl's (2009) book, Public produce, in which he suggests that urban planners should design spaces for foraging, as well as horticulture and agriculture.

\section{A framework for conceptualising urban foraging practices and spaces}

The work of geographers in urban political ecology and human-plant geographies is a useful foundation for examining the place of foraging in urban landscapes generally and green spaces specifically. Urban political ecology locates the role cities play as structural components of global economic and ecological processes (Keil 2003), scrutinising the diverse ways nature in cities is metabolised by capitalist and managerialist processes and assessing how the benefits and costs of these processes are distributed. This focus recognises that marginalised groups often are not included in the way city parks are conceptualised and managed (e.g. Byrne and Wolch 2009). In identifying the forces that shape the material, social, and discursive dimensions of urban nature, urban political ecology provides a framework for understanding how the production of green space through changing material and institutional practices impacts foraging, foregrounding key questions: How do patterns of land development and urban forest distribution (Heynen 2003) affect access to the green spaces that support foraging? What species are available (Byrne and Wolch 2009)? And how do foragers navigate power relationships with land managers and owners (Brownlow 2005). Brownlow's case study of the ecologies of fear in Philadelphia illustrates how urban political ecologies may suppress or support foraging in unexpected ways, as the retreat of management during an era of urban decline led to the emergence of weedy ecologies that produced species valuable to foragers. Departing from an orthodoxy found in much urban political ecology, which takes for granted the centrality of capitalist modes of production, foraging in some of its forms must be acknowledged as a non-capitalist practice (Emery and Pierce 2005, Gibson-Graham 2008).

The emerging human-plant geographies literature offers an additional lens for understanding forager-NTFP relationships. Drawing on Latourian notions of hybridity and actor network theory, Head and Muir (2006a, 2006b) and Head and Atchison (2009) explore how relationships between people and vegetation produce particular plant assemblages in Australian yards and gardens. Although largely silent about the ways urban planning shapes the ecological characteristics of urban green space, this literature highlights how everyday interactions between plants and people persist and are bound up with personal and cultural identities, social class, and societal and individual views about nature (Head and Atchison 2009). Direct interactions with plant materials in private yards and gardens provide opportunities for urban residents to develop relationships with nature and to acquire and transmit ecological knowledge (Head and Muir 2006a, 2006b, Gross and Lane 2007). Further, plants may create and help maintain social relationships (Morgan et al. 2005, Longhurst 2006).

Emphasis on the liminal or "borderland" characteristics of urban nature practices points to the need for more complex understandings of how humans inhabit the world, including everyday "nature practices" such as yard care, gardening, and ecological restoration (Head and Muir 2006a). As "biocultural collaborative projects" (Head 2007, p. 840), humans and non-humans are co-participants and humans may take on a variety of roles. This highlights the ways in which everyday nature practices challenge the salience of ecological concepts such as indigeneity and non-indigeneity as well as transcend boundaries intended to separate nature in parks from the nature practices of backyards (Head and Muir 2006b). It opens 
the possibility for green space policies that conceptualise humans as embedded within ecosystems and recognise the potential for foraging to play a generative role in the production and maintenance of desirable urban ecologies (Head 2007). Hurley et al.'s (2013) work on sweetgrass basketry materials harvesting in Charleston suggests that vegetation dynamics may differentially reflect both specific landscaping practices that incorporate gatherable species and, alternatively, areas of landowner neglect. Moreover, their work highlights the importance of land-use histories and associated land-cover legacies for understanding the presence of gatherable species.

Combining urban political ecology and human-plant geographies offers an enhanced framework for understanding urban NTFPs and foraging while contributing new empirically based insights into these subfields. In particular, careful attention to the everyday nature practices of urban foraging offers a new perspective from which to examine the socio-ecological forces shaping urban ecologies and the politics of urban green space management. Urban foraging studies draw attention to the ways in which humans actively resist the dominant green space management paradigm that views humans as separate from nature and highlight the socio-ecological importance of interstitial green spaces. Further, the examination of urban foraging practices has the potential to aid researchers in deriving scalar insights into the workings of urban socio-ecological processes and power dynamics that shape the interaction of individual people, plants, and mushrooms, including ideologies and institutions ranging from the local to the global.

\section{Urban NTFPs and foraging practices}

Studies of urban foraging in the USA are rare. In an extensive literature and internet search, McLain et al. (2012a) identified only two published studies on urban foraging in the USA other than the work discussed earlier on sweetgrass basketry material harvesting in periurban Charleston. One study was conducted in Baltimore in 1998-1999 (Community Resources 2000, Jahnige 2002); the other ("Philly I") was done in Philadelphia during 2005-2006 (Gabriel 2006). We draw on these two studies, two recent publications from an urban foraging study conducted in Seattle (McLain et al. 2012b, Poe et al. 2013), and on exploratory, unpublished research in Seattle, New York City, and the Philadelphia Metropolitan Area ("Philly II"). The research on peri-urban foraging in Charleston (Grabbitin et al. 2011, Hurley et al. 2013) is not included in our analysis because it focuses on a specific harvesting practice rather than describing a range of urban foraging practices.

\section{Data collection}

The five studies that inform our analysis of urban foraging practices in the USA gathered data from foragers and, to a lesser extent, land managers. Three of these studies were undertaken by the co-authors, while the other two represent previous and earlier work undertaken by other researchers. Data collection protocols and approaches to analysis differed somewhat across the studies, but all five of the studies employ in-depth interviewing techniques to examine foraging practices. The number of foragers interviewed ranged from 8 in Philly I to 58 in Seattle (Table 1). All of the studies collected data through semi-formal open-ended interviews. The Baltimore, Philly II, and Seattle studies also included significant time spent in direct and participation observation of foraging practices. Foragers were identified through participant observation in the real and virtual worlds and through snowball sampling in which foragers and other knowledgeable individuals suggested potential interviewees. Nonetheless, some tentative patterns can be identified when comparing the 
Table 1. Demographic characteristics of foragers interviewed in the five case studies.

\begin{tabular}{|c|c|c|c|c|c|}
\hline & $\begin{array}{c}\text { Baltimore (Community } \\
\text { Resources 2000, Jahnige 2002) }\end{array}$ & $\begin{array}{c}\text { New York } \\
\text { (unpublished data) }\end{array}$ & $\begin{array}{l}\text { Philly I (Gabriel } \\
\text { 2006) }\end{array}$ & Philly II (unpublished data) & $\begin{array}{l}\text { Seattle (Poe et al. 2013; } \\
\quad \text { unpublished data) }\end{array}$ \\
\hline $\begin{array}{l}\text { Period of } \\
\quad \text { field work }\end{array}$ & $1998-1999$ & Summer 2008 & $\begin{array}{l}\text { Spring } 2005 \text { to } \\
\text { winter } 2006\end{array}$ & $\begin{array}{l}2010 \text { to present } \\
\text { (intermittent field work) }\end{array}$ & Spring 2010 to fall 2011 \\
\hline $\begin{array}{l}\text { Number of } \\
\text { interviews }\end{array}$ & $\begin{array}{l}80 \text { interviews including } \\
\text { managers, community } \\
\text { leaders, vendors, artisans, and } \\
\text { foragers; number of foragers } \\
\text { unspecified }\end{array}$ & 11 foragers & 8 foragers & 35 foragers; 24 managers & 58 foragers; 18 managers \\
\hline Gender & Unspecified & 7 men and 4 women & Unspecified & 12 men and 12 women & $\begin{array}{l}\text { Foragers: } 22 \text { men and } 36 \text { women; } \\
\text { managers: } 9 \text { men and } 9 \text { women }\end{array}$ \\
\hline $\begin{array}{l}\text { Age range of } \\
\text { foragers }\end{array}$ & $<5$ years to 65 years & $38-61$ years & Unspecified & $\begin{array}{l}20-70 \text { years; most } \\
\text { between } 30 \text { and } 50 \text { years } \\
\text { old }\end{array}$ & $\begin{array}{l}\text { "Children" to more than } 80 \text { years } \\
\text { old (interviewees ranged from } 23 \\
\text { to } 83 \text {, but children at least as } \\
\text { young as } 5 \text { years old observed } \\
\text { foraging) }\end{array}$ \\
\hline $\begin{array}{l}\text { Ethnic/ } \\
\text { national } \\
\text { origins }\end{array}$ & $\begin{array}{l}\text { The Americas, Africa, Asia, } \\
\text { Europe; country of birth } \\
\text { status unspecified }\end{array}$ & $\begin{array}{l}\text { The Americas, Asia, } \\
\text { Europe; country of } \\
\text { birth status } \\
\text { unspecified }\end{array}$ & $\begin{array}{l}\text { Mostly unspecified; } \\
\text { two informants } \\
\text { from Puerto Rico }\end{array}$ & $\begin{array}{l}\text { Mostly unspecified, but } \\
\text { European heritage } \\
\text { sometimes invoked, } \\
\text { including one immigrant }\end{array}$ & $\begin{array}{l}\text { Africa, the Americas, Asia, Europe; } \\
\text { included both first-generation } \\
\text { immigrants and native-born } \\
\text { residents }\end{array}$ \\
\hline $\begin{array}{l}\text { Income } \\
\text { range of } \\
\text { foragers }\end{array}$ & $<\mathrm{US} \$ 10,000$ to $>\mathrm{US} \$ 100,000$ & Unspecified & Unspecified & $\begin{array}{l}<\text { US } \$ 20,000 \text { to } \\
>\text { US } \$ 250,000\end{array}$ & $<\mathrm{US} \$ 20,000$ to $>\mathrm{US} \$ 100,000$ \\
\hline
\end{tabular}


findings of the five studies. In the results that follow, we include only quotes from interviews with foragers conducted by the co-authors.

\section{Who forages for urban NTFPs}

People from all walks of life forage plants and fungi in the city (Table 1). Ages of foragers observed or interviewed ranged from less than 5 years in Baltimore to more than 80 years in Seattle. The lack of teens and children mentioned in the New York and Philly II studies likely reflects research designs in which only information on adults was recorded, rather than an absence of foragers under the age of 18. In Seattle, the only city for which data on the length of time that people had been foraging were available, the average length of time interviewees had foraged was 24 years. Income levels of foragers varied widely in the three studies where income data were collected (Baltimore, Philly II, and Seattle), ranging from less than US\$10,000 to more than US $\$ 250,000$. However, rarely was foraging the primary or even a major source of income. Foragers included both men and women.

Ethnic and racial diversity was common in most of the studies. Interviewees in Baltimore and Seattle self-identified as having national and/or cultural heritages from the Americas, Asia, Europe, and Africa. Among the 11 foragers interviewed in New York, Asia, Europe, and the Americas were represented. The Philly II study differed from the others in that all but one of the informants identified as "white" or "Caucasian". The absence of foragers of other heritages in the Philly II research, however, reflects the snowball sampling strategy rather than a lack of NTFP harvesting by individuals of other races. In Seattle, the only city for which place of origin data were collected, NTFP foragers included foreignborn and native-born residents.

The demographic diversity found among foragers in these studies meshes with results from a sample survey conducted by Robbins et al. (2008) of residents of four New England states (Massachusetts, Maine, New Hampshire, and Vermont), in which foragers tended to cross social identity boundaries, such as age, gender, and class. None of the five studies used sampling strategies that would permit an estimation of the number of people or per cent of the general population of each city that forages. However, Robbins et al. found that $18 \%$ of residents in Massachusetts, Maine, New Hampshire, and Vermont forage regularly and slightly more than half of the survey respondents who forage regularly live in urban areas. ${ }^{2}$ They did not collect specific information about whether harvest sites were in urban or rural locations.

\section{What urban NTFP foragers harvest}

Comparing the number of NTFPs harvested across the five studies is complicated owing to differences in the type of data reported. The Baltimore, New York, and Philly I studies reported both the number of species and products harvested, whereas the Seattle and Philly II studies reported only the number of species harvested. The 61 products listed by the $11 \mathrm{New}$ York foragers were derived from at least 60 plant species and 9 fungal species; the 74 products identified by just eight foragers in the Philly I study were derived from at least 70 different plant species and one fungal species (Table 2). The Baltimore project documented the harvest of 103 NTFPs from at least 78 different species. The longer term and more extensive Philly II and Seattle studies recorded the use of 165 and 486 different NTFP species, respectively. Lists of products were collected in both the Philly II and Seattle studies, but that data have not yet been analysed. 
Table 2. Number of products and species harvested, functional uses, seasonality, and livelihood activities.

\begin{tabular}{|c|c|c|c|c|c|}
\hline & $\begin{array}{l}\text { Baltimore (Community } \\
\text { Resources 2000, Jahnige } \\
\text { 2002) }\end{array}$ & $\begin{array}{c}\text { New York } \\
\text { (unpublished data) }\end{array}$ & Philly I (Gabriel 2006) & $\begin{array}{l}\text { Philly II (unpublished } \\
\text { data) }\end{array}$ & $\begin{array}{l}\text { Seattle (Poe et al. 2013; } \\
\text { unpublished data) }\end{array}$ \\
\hline $\begin{array}{l}\text { Number of } \\
\text { products and/ } \\
\text { or species } \\
\text { harvested }\end{array}$ & $\begin{array}{l}103 \text { products representing } \\
\text { at least } 78 \text { species ( } 70 \\
\text { plant and } 8 \text { fungal } \\
\text { species) }\end{array}$ & $\begin{array}{l}61 \text { products } \\
\text { representing at least } \\
60 \text { species (51 plant } \\
\text { and } 9 \text { fungal } \\
\text { species) }\end{array}$ & $\begin{array}{l}74 \text { products } \\
\text { representing at least } \\
71 \text { species ( } 70 \text { plant } \\
\text { and } 1 \text { fungal } \\
\text { species) }\end{array}$ & $\begin{array}{l}\text { Number of products } \\
\text { unspecified; } 157 \\
\text { plant, } 13 \text { fungal, and } \\
3 \text { fern species }\end{array}$ & $\begin{array}{l}\text { Number of products unspecified; } \\
433 \text { plant and } 53 \text { fungal species }\end{array}$ \\
\hline $\begin{array}{l}\text { Number of native } \\
\text { plants } \\
\text { harvested }\end{array}$ & Unspecified & Unspecified & 33 plant species & $\begin{array}{l}113 \text { species, } 97 \text { plants, } \\
13 \text { fungi, } 3 \text { fern }\end{array}$ & 195 plant species \\
\hline $\begin{array}{l}\text { Functional uses } \\
\text { of products }\end{array}$ & $\begin{array}{l}\text { Food }{ }^{\text {a }} \text { medicine, } \\
\text { horticulture or nursery, } \\
\text { crafts or decoratives }\end{array}$ & Food $^{\mathrm{a}}$, medicine & $\begin{array}{l}\text { Food }^{\text {a }}, \text { medicine, crafts } \\
\text { or decoratives, fuel, } \\
\text { cultural or spiritual }\end{array}$ & $\begin{array}{l}\text { Food }^{\mathrm{a}} \text {, medicine, } \\
\text { crafts, ecological } \\
\text { restoration }\end{array}$ & $\begin{array}{l}\text { Food }{ }^{\text {a }} \text {, medicine, arts and crafts, } \\
\text { fuel, plant salvage or } \\
\text { propagation, construction } \\
\text { materials, scientific displays, or } \\
\text { education }\end{array}$ \\
\hline $\begin{array}{l}\text { Seasonality of } \\
\text { harvest }\end{array}$ & $\begin{array}{l}\text { Year-round; most intense in } \\
\text { spring and late summer/ } \\
\text { fall }\end{array}$ & $\begin{array}{l}\text { March to December; } \\
\text { spring and fall most } \\
\text { intense }\end{array}$ & $\begin{array}{l}\text { Early spring to fall; } \\
\text { most intense in } \\
\text { spring/early summer } \\
\text { and fall }\end{array}$ & $\begin{array}{l}\text { Year-round; most } \\
\text { intense during } \\
\text { spring and fall }\end{array}$ & $\begin{array}{l}\text { Year-round; most intense in spring, } \\
\text { summer, fall }\end{array}$ \\
\hline $\begin{array}{l}\text { Livelihood } \\
\text { activities } \\
\text { associated with } \\
\text { urban foraging }\end{array}$ & $\begin{array}{l}\text { Mostly personal } \\
\text { consumption; some } \\
\text { gifting, some products } \\
\text { are sold (both in raw and } \\
\text { value-added forms) }\end{array}$ & Unspecified & $\begin{array}{l}\text { Mostly personal } \\
\text { consumption; some } \\
\text { products sold in } \\
\text { value-added form }\end{array}$ & $\begin{array}{l}\text { Mostly personal } \\
\text { consumption; some } \\
\text { sales of raw and } \\
\text { value-added } \\
\text { products }\end{array}$ & $\begin{array}{l}\text { Personal consumption dominates, } \\
\text { bartering/trade is also common, } \\
\text { some sales of raw and value- } \\
\text { added products, some foragers } \\
\text { earn income by teaching others to } \\
\text { forage }\end{array}$ \\
\hline
\end{tabular}

Most frequently mentioned use. 
In all of the studies, products consisted of whole plants (or fungi) or were derived from a variety of above- and below-ground parts: bark, flowers, fruit, leaves, roots, stems, etc. Foraged products in each of the cities included both native and non-native species. In the two studies (Philly I and Seattle) where a breakdown was made, slightly more than half the species harvested were non-natives. Prominent among the non-native species are many edible fruit and nut species including common apple (Malus domestica), Chinese chestnut (Castanea mollissima), European or sweet chestnut (Castanea sativa), ginkgo (Ginkgo biloba), European plum (Prunus domestica), and European pear (Pyrus communis).

Edibles, including berries, fruits, nuts, greens, and young shoots, were by far the most frequently mentioned type of product in each study site. The nine top species listed by foragers in New York were all gathered for food (Table 3). Likewise the top nine species mentioned by the Seattle and Philly II foragers were used for food, though some foragers also harvested parts of those species for purposes other than eating. In the Philly II study, only two people collected items for anything other than food or medicine - one for basketry and the other for crafts (including dyes). Native trees species with edible fruits and nuts were also targeted in Philadelphia, including black walnut (Juglans nigra), beach plum (Prunus maritima), paw paw (Asimina triloba), and numerous types of hickory (Carya spp.).

In some cases, foragers' ethnicity and/or place of origin appear to condition which products are foraged. For example, Chinese immigrants sought ginkgo nuts (G. biloba) in Baltimore, New York, and Philadelphia; African-Americans in Baltimore and Philadelphia foraged young pokeweed shoots (Phytolacca americana); and American Indians in Seattle harvested evergreen huckleberries (Vaccinium ovatum) and nettle leaves (Urtica dioica). Managers in the Philly II study also describe talking with foragers of Italian, Hispanic, and Eastern European origin, many seeking prized species for family recipes (e.g. morel mushrooms (Morchella spp.) and greens common in Europe) or carrying on traditions of foraging practised in their sending countries (e.g. harvesting mushrooms).

\section{Frequency, intensity, and seasonality of urban foraging}

In all five studies, the frequency and purposefulness with which individuals foraged ranged from participating in planned forays multiple times each year to opportunistic berry picking incidental to a hike or other outing. In New York, Philadelphia, and Seattle, some foragers lead gathering tours or forays in city green spaces each year, providing dozens to hundreds of people their first urban foraging experience. Gathering occurred year-round in Baltimore, Philadelphia, and Seattle, and from March through December in New York. However, gathering in these cities, located in temperate climate zones with cold winters and warm summers, exhibited two peak periods: in spring when young leaves, shoots, and morel mushrooms are commonly gathered and in late summer and early fall when many fruits, nuts, and the majority of wild edible species of fungi are abundant.

\section{Motivations for urban foraging}

Participants in the five studies came to foraging through a variety of paths and their motivations are often diverse. One New Yorker began foraging with a great-grandmother from Greece who, after immigrating to the USA, carried on the village tradition of harvesting spring greens. Another New York forager was inspired to learn about wild foods when she observed a friend adding plant leaves to her sandwich as they were eating lunch outdoors. Indeed, food and eating are strong motivators for many interviewees. A few report that hunger and limited financial means are or have been motivating factors. 
Table 3. Top nine salient species gathered in New York, Philadelphia, and Seattle.

\begin{tabular}{|c|c|c|c|}
\hline Latin name & Common name & Uses & Parts used \\
\hline \multicolumn{4}{|l|}{ New York } \\
\hline Amelanchier spp. & Juneberry & Food & Berries \\
\hline Alliaria petiolata & Garlic mustard & Food & Leaves \\
\hline Morus spp. & Mulberry & Food & Berries \\
\hline Rubus spp. & Blackberries & Food & Berries \\
\hline Corylus spp. & Hazelnut & Food & Nut \\
\hline Polygonum spp. & Knotweed & Food & Unspecified \\
\hline Chenopodium album & Lambs quarter & Food & Unspecified \\
\hline Pleurotus ostreatus & Oyster mushrooms & Food & Unspecified \\
\hline Lindera benzoin & Spicebush & Food & Berries \\
\hline \multicolumn{4}{|l|}{ Philadelphia (Philly II) } \\
\hline $\begin{array}{l}\text { Rubus } \\
\text { phoenicolasius }\end{array}$ & Japanese Wineberry & Food & Fruit \\
\hline Juglans nigra & Black walnut & Food, craft/dye & Fruit \\
\hline Taraxacum officinale & Dandelion & Food, medicine & $\begin{array}{l}\text { Leaves, flower, } \\
\text { root }\end{array}$ \\
\hline Amelanchier arborea & Serviceberry & Food & Fruit \\
\hline Prunus maritima & Beach plum & Food & Fruits \\
\hline Rubus allegheniensis & Common blackberry & Food & Fruits \\
\hline $\begin{array}{l}\text { Vaccinium } \\
\text { corymbosum }\end{array}$ & Highbush blueberry & Food & Fruits \\
\hline Morchella esculenta & Morel mushroom & Food & Fruiting body \\
\hline Alliaria petiolata & Garlic mustard & Food & Fruits \\
\hline \multicolumn{4}{|l|}{ Seattle } \\
\hline $\begin{array}{l}\text { Mahonia nervosa } \\
\text { (Berberis) }\end{array}$ & $\begin{array}{l}\text { Low or dull Oregon Grape, } \\
\text { cascade barberry, } \\
\text { narrowleaf mahonia }\end{array}$ & $\begin{array}{l}\text { Food, medicine, } \\
\text { craft/dye }\end{array}$ & $\begin{array}{l}\text { Fruits, bark, roots, } \\
\text { stems, tender } \\
\text { leaves }\end{array}$ \\
\hline Malus domestica & Apple & Food, spiritual, skin care & Fruit, branch, bark \\
\hline Pleurotus ostreatus & $\begin{array}{l}\text { Oyster mushroom, hiratake, } \\
\text { tamogitake }\end{array}$ & $\begin{array}{l}\text { Food, choice edible; } \\
\text { potential for } \\
\text { mycorestoration }\end{array}$ & $\begin{array}{l}\text { Fruiting body; } \\
\text { mushroom }\end{array}$ \\
\hline $\begin{array}{l}\text { Prunus domestica } \\
\text { (cerasifera, } \\
\text { spinosa) }\end{array}$ & European plum & Food & Fruit, branches \\
\hline Rubus armeniacus & $\begin{array}{l}\text { Himalayan blackberry, } \\
\text { common blackberry }\end{array}$ & $\begin{array}{l}\text { Food; craft, weaving, } \\
\text { fencing }\end{array}$ & Fruit, stems \\
\hline Rubus laciniatus & $\begin{array}{l}\text { Evergreen blackberry, } \\
\text { Oregon blackberry }\end{array}$ & Food & Fruit \\
\hline Rubus spectabilis & $\begin{array}{l}\text { Salmonberry, woodman's } \\
\text { rose }\end{array}$ & Food & $\begin{array}{l}\text { Fruit, young } \\
\text { shoots, blossom }\end{array}$ \\
\hline Taraxacum officinale & Dandelion & Food, medicine & $\begin{array}{l}\text { Leaves, flowers, } \\
\text { roots }\end{array}$ \\
\hline Urtica dioica & Stinging nettle & $\begin{array}{l}\text { Food; medicine; craft, } \\
\text { cordage }\end{array}$ & $\begin{array}{l}\text { Young leaves, } \\
\text { root, stems, } \\
\text { seeds, stalk }\end{array}$ \\
\hline
\end{tabular}

Among the foragers interviewed, the livelihood values of urban NTFPs derive primarily from non-market strategies (Table 2).

Interviewees frequently expressed joy in the flavours and what they believe are the healthful benefits of wild foods, as well as the satisfaction of eating something they have picked themselves. As one forager in the Philly II study noted when asked 
about motivations for foraging, “... It's obviously not for survival - I can easily get enough food without gathering. It's just a hobby of mine... The health benefits of eating wild foods are a big factor for me". Foragers in New York and Seattle expressed similar sentiments:

I love to eat and I love to cook .... I love being able to look around and to see if there were not food could I survive? What would I do? But also there is something about the direct contact between the earth and picking, it being in your area and it being local. That's important to me. (New York forager)

It's kind of a big cultural, a big tradition in my family to pick enough berries and just to kind of love that experience so much and then put that love into whatever you're eating and kind of continue the experience of being outside in the kind of bounty of nature into sharing that with people. That whole - it's definitely a tradition, something that we all value. (Seattle forager)

Regardless of length of residence, foraging is one avenue through which many seek to connect to and care for their environment:

[Gathering] connects me with the environment. I'm so much more in tune with the environment because I guess I have a particular reason to be in tune with it .... It nourishes your body and soul, I guess (laughs). You gain a whole relationship with the tree and the place where the tree is, and then you watch it during the season because you know it's going to hopefully produce the fruit that you can come to and then you become more tied to the rhythms of the place where you are .... It kind of gives you peace of mind. (Philly II forager)

The most important part is the relationship I have with the place that I live. It is an intimate connection... I mean you can go out and you can appreciate it and say "oh, my isn't it pretty" and people can show you and you can learn by that. But when you interact on this level, when it becomes part of your pantry, when it is part of what you eat, now you have a relationship. You're not an outsider observer. It's not this "other" thing. It's part of you and you're part of it. (Seattle forager)

In this light, foraging can be seen as a deeply relational practice connecting humans with nature, other humans, and their inner selves.

\section{Knowledge production and sharing}

Knowledge production and sharing are important aspects of urban foraging. In each of the five studies, people describe acquiring and passing on information about NTFPs and foraging in many ways including through family and friends, amateur mycological society outings, professional botanists, books, and field guides (see e.g. Brill and Dean 1994, Jacobson 2008). Several of the foragers interviewed in New York City, Seattle, and Philadelphia provide formal instruction on foraging through field tours, workshops, or wilderness awareness schools. Professionally trained ecologists and resource managers were among the foragers interviewed in New York, metropolitan Philadelphia, and Seattle.

Economic mobility, social media, and social networking appear to be key factors in the sharing of knowledge and enacting of urban foraging practices. In the last 5-10 years, the Internet also has become a source of information on foraging as well as a place where foragers organise outings. The Wild Foodies, a Philadelphia meet-up group mentioned at the outset of this article, hosts regular forays, an active blog, and an online plant identification guide. Wild Foodies is an example of the rapidly emerging virtual and physical social networks connecting urban foragers, spaces, and species. Several other types of organisations also have emerged in the past decade to facilitate access to existing urban fruit trees (often in 
private yards but sometimes in public spaces) or expand public access to fruit and other edible products through the establishment of public orchards (McLain et al. 2012a). These organisations include community-based backyard fruit harvesting programmes (e.g. Portland Fruit Tree Project 2010), community-based public urban orchard programmes (e.g. Philadelphia Orchard Project 2007), and web-based interactive fruit mapping efforts (e.g. Fallen Fruit n.d.) in Los Angeles. More recently, smartphone technologies - specifically downloadable "apps" - provide mobile field guides for foraging (Brill 2012) and access to online maps of accessible species.

\section{Urban foraging spaces, regulations, and green space policies}

Participants interviewed in the four case study cities forage in formal green spaces and in the interstitial spaces where plants and fungi grow without influence of official management (Table 4). Examples of the former include parks large and small, cemeteries, botanical gardens, corporate and institutional grounds, and residential yards. Vacant lots, fence lines, shorelines, and the ends and edges of public and private rights of way (e.g. utility corridors and roadside strips) exemplify the latter. In Baltimore and Philadelphia, more intensive gathering appears to take place in parks, arboretums or other institutional grounds with tree collections, and natural areas, and along streets in neighbourhoods with an abundance of fruit and nut trees (Jahnige 2002, Gabriel 2006).

A variety of factors influence the availability and quality of desirable NTFP species, as well as whether foragers can legally gain access to them. Chief among these factors are regulations governing the collection and planting of NTFP species, vegetation management and land-use practices, and managerial perceptions of NTFP harvesting.

\section{Formal rules regarding NTFP collection}

Urban foraging opportunities in public spaces, such as parks and natural areas, and in quasipublic spaces, such as the strips between sidewalks and streets, are affected by formal rules governing the collection of plants, plant parts, and fungi. In parks and natural areas, collecting is often either prohibited or limited to the harvesting of fruits, berries, or nuts. Harvest for personal consumption, not commercial sale, is commonly a further limitation. However, the regulations can change from one jurisdiction to the next, resulting in a complex patchwork of urban foraging rules across the landscape. For example, Philly II project researchers found that NTFP harvesting is prohibited outright in land trust preserves and some county parks, while other county parks, state parks, and Valley Forge National Park restrict harvesting to edible fruits, nuts, and berries for personal use. Section 18-129 of New York City's Parks and Recreation Department Code states that it is unlawful to "cut, remove or in any way destroy or cause to be destroyed, any tree or other form of vegetation on public property" under the park commissioner's jurisdiction. Seattle is an exception in that the Seattle Parks and Recreation Department has recently updated their policy to permit foraging as long as the quantities harvested are small. Baltimore's city parks do not explicitly prohibit the collection of fungi and plant material, although Section 52-2 of the city's Natural Resources Code states that persons are not permitted to "injure the grass, trees, or shrubbery" in Mount Vernon Place Park. Section 30-2-201 of Baltimore County's Recreation and Parks Code states that persons may not "damage or destroy flora in a park" without permission of the Recreation and Parks Department, leaving open to interpretation whether some types of harvesting, such as the picking of fruit or berries, 
Table 4. Urban foraging spaces.

\begin{tabular}{|c|c|c|c|c|}
\hline $\begin{array}{l}\text { Baltimore } \\
\text { (Community } \\
\text { Resources 2000, } \\
\text { Jahnige 2002) }\end{array}$ & $\begin{array}{l}\text { New York } \\
\text { (unpublished } \\
\text { data) }\end{array}$ & $\begin{array}{l}\text { Philly I } \\
\text { (Gabriel } \\
\text { 2006) }\end{array}$ & $\begin{array}{l}\text { Philly II } \\
\text { (unpublished data) }\end{array}$ & $\begin{array}{l}\text { Seattle } \\
\text { (unpublished data) }\end{array}$ \\
\hline $\begin{array}{l}\text { - Parks } \\
\text { - Natural areas } \\
\text { - Institutional } \\
\text { grounds } \\
\text { - Private yards } \\
\text { - Vacant lots } \\
\text { - Street trees/ } \\
\text { vegetation } \\
\text { - Edges and ends of } \\
\text { public rights of way }\end{array}$ & $\begin{array}{l}\text { - Parks } \\
\text { - Botanical } \\
\text { gardens } \\
\text { - Cemeteries } \\
\text { - Vacant lots } \\
\text { - Street trees }\end{array}$ & $\begin{array}{l}\text { - Parks } \\
\text { - Private } \\
\text { yards } \\
\text { - Vacant } \\
\text { lots } \\
\text { - Street } \\
\text { trees }\end{array}$ & $\begin{array}{l}\text { - Parks } \\
\text { - National parks } \\
\text { - State parks } \\
\text { - County parks } \\
\text { - City parks } \\
\text { - Land trust } \\
\text { - Sreserves } \\
\text { - Rtate game lands } \\
\text { - } \text { trails } \\
\text { - Colborional } \\
\text { campuse } \\
\text { - Private yards } \\
\text { - Street trees } \\
\text { - Roadsides } \\
\text { - Fencerows } \\
\text { - Power easements }\end{array}$ & $\begin{array}{l}\text { - Parks } \\
\text { - Forest/woods } \\
\text { - Former orchards/ } \\
\text { farmland } \\
\text { - Prairies/fields } \\
\text { - Wetlands/prairies } \\
\text { - Shorelines } \\
\text { - Stream banks } \\
\text { - Trails } \\
\text { - Institutional } \\
\text { grounds } \\
\text { - Cemeteries } \\
\text { - Community } \\
\text { gardens } \\
\text { - Private yards/ } \\
\text { gardens } \\
\text { - Abandoned, } \\
\text { foreclosed } \\
\text { properties } \\
\text { - Empty lots } \\
\text { - Sidewalks } \\
\text { - Parking strips } \\
\text { (street trees) } \\
\text { - Alleys } \\
\text { - "Edges" } \\
\text { - Roadsides } \\
\text { - Railroad tracks } \\
\text { - Industrial areas } \\
\text { - Under freeways } \\
\text { - Containers } \\
\text { - Wood chips/bark } \\
\text { in landscaping } \\
\text { areas } \\
\text { - }\end{array}$ \\
\hline
\end{tabular}

might be considered acceptable. Despite these regulations, foraging of a large variety of plants and fungi occurs in parks and natural areas in all four cities.

Rules governing street trees also affect access to NTFPs. Within Philadelphia's city limits, for example, street tree regulations prohibit the picking of flowers, branches, and other tree parts, leaving unclear whether the collection of fruits and nuts is also meant to be included (Gabriel 2006). Similarly, although Section 53-22a of Baltimore's Natural Resource Code penalises persons who "willfully break, pull down, hurt, or destroy any tree or trees", the Code does not state whether the gathering of fruits, nuts, seed pods, or blossoms is permitted. In Seattle, the question of who has legal access to NTFPs from street trees is complicated, as 
some street trees are owned by the city while others are owned by adjacent landowners who have the responsibility for maintaining them (McLain et al. 2012b). Presumably - though the regulations do not state so explicitly - street tree owners in Seattle have the rights to products that can be harvested without damaging the trees.

The Philadelphia Metro Area, as suggested in this article's opening vignette, illustrates the complexity of governance regimes facing foragers in the (sub)urban forest. County parks and land trust preserves in the area prohibit gathering, but interviews with managers in one county reveal that the wording of their ordinances allows them some flexibility in enforcement. This can lead to de facto allowances for, in most cases, berry or nut collecting. At the same time, area national parks, state parks, and state game lands permit some species to be collected, limited to nuts and berries in the first two instances while mushrooms and additional items can be collected in state game lands. Research is just beginning to document the complexity of rules governing the area's several hundred municipal parks, but prohibitions on collecting - with some interesting exceptions (e.g. buttercups (Ranunculus spp.) and dandelions (Taraxacum spp.)) - are a recurring theme. Nevertheless, interviews with managers of diverse park types indicate that foraging is present and enforcement may hinge on whether a particular individual appears to be gathering a species in a responsible manner. Some managers themselves admit to collecting NTFPs. One manager interviewed in the Philly II study said, "I've actually engaged in some [foraging] myself" and 7 of the 26 managers and conservation practitioners interviewed in Seattle stated that they foraged, generally for berries.

\section{Rules restricting the types of species that can be planted}

Rules restricting the types of species that private landowners can plant adjacent to streets also influence urban foraging opportunities in these readily accessible and public or quasi-public spaces. For example, to reduce health and safety risks associated with fallen fruits, Seattle prohibits landowners from planting apple (Malus spp.), cherry (Prunus spp.), and pear (Pyrus spp.) trees in street strips (McLain et al. 2012b). The approved street tree lists for New York, Philadelphia, and Baltimore emphasise non-fruiting varieties of common fruit trees, although trees with edible nuts, such as oaks (Quercus spp.), are listed as approved species in all three cities, and Philadelphia includes several hickory (Carya spp.) species. Interviews with New York City managers, however, reveal that some neighbourhoods may engage in "guerilla" planting of fruit trees, which may be tolerated by individual managers and foresters.

\section{Vegetation management and land-use practices}

Vegetation management practices of public agencies, businesses, or private individuals affect opportunities for urban foraging by shaping which species are available in different types of urban spaces. A source of concern among foragers in all four cities was the spraying of chemical herbicides and pesticides on lawns, roadsides, railroad tracks, and utility rights of way. A forager interviewed in the Philly II study noted that

Actually, the biggest problem I have with foraging is just [that] there's so much parks, grounds, that's sprayed. Like I now can see people sprayed their lawns with all kinds of things, so you can't just pick off anybody's lawn.

Many foragers also express concern about the quality of products harvested in areas with soils that are likely to have been contaminated from previous or current use as 
industrial production sites, waste dumps, or transportation corridors. For example, Gabriel (2006) reports that the foragers he interviewed tended to avoid vacant lots in former industrial areas. Many foragers in Seattle refrained from harvesting along railroad tracks and heavily travelled roads, in industrial areas, and under freeways owing to fears that products gathered in such sites might be contaminated.

The recent interest in ecological restoration and concomitant efforts to expand native species populations and reduce or eliminate both exotic species and native and non-native invasive species, particularly in parks, has also elicited concerns among some foragers. Invasive species, such as Asiatic bittersweet (Celastrus orbiculatus) and multi-flora rose (Rosa multiflora), which are frequent targets for eradication in area parks, offer useful material for the lone local basket-maker in the Philly II study. In New York City, Japanese knotweed (Polygonum cuspidatum), mugwort (Artemisia vulgaris), and garlic mustard (Alliaria petiolata) - recurrent park "weeds" to be eliminated - are targeted by foragers of diverse backgrounds, seeking either familiar foods from "home" or interesting ingredients for personal meals. However, as Gabriel (2006) points out, the emphasis on restoring non-invasive native species can be positive for those foragers who seek products from such species.

\section{Awareness/attitudes about harvesting/harvesters}

Most conservation practitioners interviewed in these studies had a negative or, at best, ambivalent view about the desirability of allowing or encouraging foraging, particularly in parks or natural areas. Although managers of diverse types of parks in the Philly II study have observed foragers harvesting in their parks, they see the activity as a minor component of park use. Nonetheless, they stress the importance of protecting "the resource" and are sceptical of policy change. Likewise, park managers in New York City consistently describe foraging as an inappropriate and incompatible use. As one manager described the case of immigrants collecting products from Asian species:

Here we sort of revere [our parks] and treat them as a museum. Other places there's much more of a working forest [approach]. You're not supposed to be harvesting things off of city land for, well at all really ... But especially for, you know, commercial use, that's not something that we would ever want to encourage. (New York City manager)

Exceptions are sometimes made, for example, in considering the role that foragers might play in "cleaning up" messy fruits. Managers in New York City offered the example of (assumed) Asian immigrants collecting ginkgo ( $G$. biloba) nuts as one possible exception. In Seattle, views about foraging among conservation practitioners varied considerably. Some considered foraging to be destructive and a practice that should not be permitted, others felt that low levels of harvesting, particularly of invasive or non-native species, were acceptable, and a small minority stated that they were considering how foraging could be integrated into ecological restoration activities.

Indeed, many harvesters speak of foraging as a constructive and interactive nature practice that benefits both the forager and the areas in which foraging takes place. All of the studies documented numerous examples of intentional stewardship activities practised by urban foragers. For example, many harvesters, such as the one quoted below from Seattle, harvest selectively for sustainable returns over time, avoiding harvests in areas with small populations:

I do a lot of poking around, or sometimes the places change, or the plants aren't as abundant.

I'm pretty careful about choosing to harvest places where the plants are quite abundant. And if 
it seems that the plant is starting to diminish - like I was harvesting watercress in one spot, and it really seems like it was diminishing, so I just stopped harvesting there and found another spot. I'm constantly interacting with the environment, evaluating, and assessing what's happening, whether it's the best location to harvest or not. (Seattle forager)

Other stewardship practices reported included harvesting only a portion of the material available, tending individual specimens or populations, pruning and propagating valued species, and removing those considered invasive. Some foragers described bringing in transplants to increase populations of species perceived to be diminishing in abundance.

Of the four cities, Seattle and Philadelphia are the furthest along in rethinking the role of foraging in urban green spaces. The Seattle Parks and Recreation Department is actively seeking to rehabilitate former apple orchards in city parks, trees that it had neglected for decades. In 2012, the city approved the establishment of an experimental food forest in a neighbourhood park, and the Parks and Recreation Department recently updated its regulations to permit foraging, provided that quantities harvested are small. Philadelphia has followed a similar path and is supporting efforts by the non-profit organisation, Philadelphia Orchard Project, to establish public orchards in sites throughout the city, including revitalisation of the Woodford Orchard in East Fairmont Park. The re-establishment of fruit picking in Fairmont Park brings the city back full circle to the late 1800 s, when the park's commissioners welcomed thousands of school children every Nutting Day, a local holiday at the time, to the park to harvest chestnuts, walnuts, and hazelnuts (Gabriel 2011). At the same time, Philadelphia seems quite hesitant to expand foraging beyond these forms of agricultural produce harvesting, with other types of foraging prohibited on park lands.

\section{Discussion}

The empirical research presented here from Baltimore, New York, Philadelphia, and Seattle reveals that foraging is one of the complex ways in which urban residents actively relate with plants and fungi found in urban parks and interstitial green spaces. These exploratory studies point to the importance for planners, managers, and scholars to understand urban green spaces as not only providers of services, but also providers of material products. Numerous NTFPs are found in cities and diverse types of people depend upon and take delight in harvesting - and often, nurturing - the species from which those products are derived. The spaces in which foraging occurs, like those dedicated to urban agriculture, constitute landscapes of material production in the city and are important for more than just their aesthetic, recreational, and ecological values. The practices of urban foraging, like those of urban agriculture, blur long-entrenched distinctions between urban and rural uses of nature.

Embracing foraging as a legitimate use of parks and other green spaces in US cities represents a new challenge for urban green space planners and managers. The evidence from exploratory work in Baltimore, New York, Philadelphia, and Seattle suggests that including urban NTFPs and foraging practices in green space planning offers multiple opportunities for supporting sustainable urban ecosystem management. First, many foragers have detailed knowledge about urban green spaces and species, which could enhance understandings of ecological relationships and change. This information could be helpful for informing management discussions and decisions about sustainable cities. Second, given that foraging practices appear to be important for maintaining cultural identities and have the potential to contribute to food security and human and community well-being, urban green space planning that incorporates urban foraging considerations has the potential to 
be more inclusive and environmentally just. Third, in broadening the distribution of benefits of urban ecosystem management, urban green space planners may enlarge their base of support for maintaining or expanding existing green infrastructure.

Incorporating foraging and urban NTFPs into urban green space planning is likely to pose a number of challenges. Densely human-populated areas clearly present challenges to the establishment of sustainable harvesting regimes. Determining which species can or should be harvested, and at what levels, is likely to be resource intensive and contentious. For example, some urban NTFPs may require inventorying and monitoring to ensure sustainability over time, while others may not. Likewise, if increases in the populations and distributions of fruit-bearing species are pursued, unharvested fruits may be perceived as messy and attractive to vermin. These changes may lead to increases in the cost of everyday park maintenance. Negotiating the establishment and management of access will not be simple or without some degree of conflict. Harvest volumes and seasonal timing may be difficult to establish, while identifying and engaging foragers as well as incorporating their needs may take time.

Green space planning processes are already well positioned to incorporate forager participation, while new policy discussions suggest possible ways forward. Most green space planning texts include sections on community participation and community engagement. These same approaches can be used to engage foragers. Urban fruit harvesting and gleaning are already acquiring a degree of legitimacy as a food security strategy for low-income urban residents and as a local food production strategy for people of all income levels. In the process, the harvest of fruits and nuts from public and quasi-public green spaces is gradually becoming legitimate in the eyes of urban planners (McLain et al. 2012b). These spaces include streetscapes as well as orchards in parks, church yards, and school yards (Nordahl 2009).

Recognising the everyday practices of urban foraging has implications for research in urban political ecology and human-plant geographies. To date, urban political ecology has tended to reinforce notions of rural-urban difference by failing to recognise that classic resource conflicts well documented in the "rural geography" literature are also present in the city. As a productive nature practice, urban foraging reveals tensions over land tenure, access, and environmental management in the city that are new to urban political ecology. Foraging in the city points to a set of persistent practices and emergent urban relationships with nature that is neither entirely urban nor rural. While human-plant geographers have recognised heterogeneous urban spaces, including green space and gardens as well as ways that productive practices transgress boundaries and categories, this focus has tended towards an emphasis on species indigeneity or non-indigeneity. Urban foragers represent an additional set of actors and practices through which to explore the binaries, boundaries, and management logics that shape everyday nature interactions in the city. The relationship between foragers and plants opens up a new line of inquiry into the role that feral and non-domesticated species play in shaping human-plant geographies. From a practical standpoint, conservation scientists in Sweden (Barthel et al. 2005), Japan (Kobori and Primack 2003), and New Zealand (Wehi and Wehi 2009) describe positive links between biodiversity and cultural practices in some urban landscapes and call for conservation practitioners to recognise that harvesting products from urban forests need not be at odds with biodiversity conservation goals. Furthermore, under some circumstances managers might find that they can accomplish ecological goals through the strategic encouragement of certain types of gathering. With this in mind, urban foraging (like other anthropogenic drivers) may contribute positively to social and ecological resilience in the face of broad-scale political ecological change. 


\section{Funding}

Research funded by USDA-Forest Service, PNW Research Station (American Recovery and Reinvestment Act Funding). The roles of NTFPs gathering and stewardship in fostering healthy ecosystems in King County, Washington [Contract JVA \#: PNW 10 JV 11260489-024]. USDA-Forest Service, PNW Research Station. Institutional analysis of NTFPs gathering in Seattle, Washington [Contract JVA \#: PNW 09 JV 11261975-056].

\section{Notes}

1. Ruderal species are those that establish themselves in areas characterised by ruins, waste dumps, pavement edges, and similar habitats.

2. It is noteworthy that these percentages exceed national participation rates in the USA for golfing (16.7\%), hunting (11.4\%), and backpacking (10.3\%) (Robbins et al. 2008).

\section{References}

Barthel, S., et al., 2005. History and local management of a biodiversity-rich, urban cultural landscape. Ecology and Society [online], 10 (2). Available from: http://www.ecologyandsociety.org/ vol10/iss2/art10/ [Accessed 11 February 2013].

Beatley, T., 2011. Biophilic cities: integrating nature into urban design and planning. Washington, DC: Island Press.

Benedict, M. and McMahon, E., 2006. Green infrastructure: linking landscapes and communities. Washington, DC: Island Press.

Botkin, D.B. and Beveridge, C.E., 1997. Cities as environments. Urban Ecosystems, 1 (1), 3-19.

Brill, S., 2012. Wild edibles. Mobile app for Android. New York: Winterroot LLC.

Brill, S. and Dean, E., 1994. Identifying and harvesting edible and medicinal plants in wild (and not so wild) places. New York: HarperCollins.

Brownlow, A., 2005. An archaeology of fear and environmental change in Philadelphia. Geoforum, 37 (2), 227-245.

Byrne, J. and Wolch, J., 2009. Nature, race, and parks: past research and future directions for geographic research. Progress in Human Geography, 33 (6), 743-765.

Certomà, C., 2011. Critical urban gardening as a post-environmentalist practice. Local Environment, 16 (2), 977-987.

Community Resources, 2000. The bounty of the urban forest: the uses and values of urban non-timber forest products [online]. Available from: http://www.urbanforestrysouth.org/resources/library/ the-bounty-of-the-urban-forest-the-uses-and-values-of-urban-non-timber-forest-products/file [Accessed 11 February 2013].

Craft, D., 2010. Urban foraging: finding and eating wild plants in the city. Memphis, TN: Serviceberry Press.

Cronon, W., 2000. Resisting monoliths and Tabulae rasae. Ecological Applications, 10 (3), 673-675.

Del Tredici, P., 2010. Spontaneous urban vegetation: reflections of change in a globalized world. Nature and Culture, 5 (3), 299-315.

Emery, M.R. and Pierce, A.R., 2005. Interrupting the telos: locating subsistence in contemporary US forests. Environment and Planning A, 37 (6), 981-993.

Erickson, D., 2006. MetroGreen: connecting open space in North American cities. Washington, DC: Island Press.

Fábos, J., 2004. Greenway planning in the United States: its origins and recent case studies. Landscape and Urban Planning, 68 (2-3), 321-342.

Fallen Fruit, n.d. Fallen Fruit [online]. Available from: www.fallenfruit.org [Accessed 16 September 2013].

Foderaro, L.W., 2011. Enjoy park greenery, city says, but not as salad. The New York Times [online], 29 July. Available from: http://www.nytimes.com/2011/07/30/nyregion/new-york-moves-to-stopforaging-in-citys-parks.html [Accessed 11 February 2013].

Gabriel, N., 2006. Urban non-timber forest products in Philadelphia. Master's thesis. Temple University, Philadelphia, PA.

Gabriel, N., 2011. The work that parks do: towards an urban environmentality. Social and Cultural Geography, 12 (2), 123-141. 
Gibson-Graham, J.K., 2008. Diverse economies: performative practices for "other worlds". Progress in Human Geography, 32 (5), 613-632.

Gobster, P., 2007. Urban park restoration and the "museumification" of nature. Nature and Culture, 2 (2), 96-114.

Grabbatin, B., Hurley, P.T., and Halfacre, A.C., 2011. "I still have the old tradition": the co-production of sweetgrass basketry and coastal development. Geoforum, 42 (6), 638-649.

Gross, H. and Lane, N., 2007. Landscapes of the lifespan: exploring accounts of own gardens and gardening. Journal of Environmental Psychology, 27 (3), 225-241.

Head, L., 2007. Cultural ecology: the problematic human and the terms of engagement. Progress in Human Geography, 31 (6), 837-846.

Head, L. and Atchison, J., 2009. Cultural ecology: emerging human-plant geographies. Progress Human Geography, 33 (2), 236-245.

Head, L. and Muir, P., 2006a. Edges of connection: reconceptualising the human role in urban biogeography. Australian Geographer, 37 (1), 87-101.

Head, L. and Muir, P., 2006b. Suburban life and the boundaries of nature: resilience and rupture in Australian backyard gardens. Transactions of the Institute of British Geographers, 31(4), 505-524.

Heynen, N.C., 2003. The scalar production of injustice within the urban forest. Antipode, 35 (5), 980 998.

Hurley, P.T., et al., 2008. Finding a "disappearing" nontimber forest resource: using grounded visualization to explore urbanization impacts on sweetgrass basketmaking in Greater Mt. Pleasant, SC. Professional Geographer, 60 (4), 1-23.

Hurley, P.T., et al., 2013. Gathering, buying, and growing grass: urbanization and social networking in the sweetgrass basket-making industry of Lowcountry South Carolina. In: R. Voeks and J. Rashford, eds. African ethnobotany in the Americas. New York: Springer, 153-174.

Jacobson, A.L., 2008. Wild plants of greater Seattle. Seattle, WA: Arthur Lee Jacobson.

Jahnige, P., 2002. The hidden bounty of the urban forest. In: E.T. Jones, R.J. McLain, and J. Weigand, eds. Nontimber forest products in the United States. Lawrence: University Press of Kansas, 96-101.

Kambites, C. and Owen, S., 2006. Renewed prospects for green infrastructure planning in the UK. Planning Practice and Research, 21 (4), 483-496.

Keil, R., 2003. Urban political ecology. Urban Geography, 24 (8), 723-738.

Kobori, H. and Primack, R.B., 2003. Participatory conservation approaches for Satoyama, the traditional forest and agricultural landscape of Japan. Ambio, 32 (4), 307-311.

Longhurst, R., 2006. Plots, plants, and paradoxes: contemporary domestic gardens in Aotearoa/New Zealand. Social and Cultural Geography, 7 (4), 581-593.

Lovell, S.T., 2010. Multifunctional urban agriculture for sustainable land use planning in the United States. Sustainability, 2 (8), 2499-2522.

McLain, R.J., et al., 2012a. Gathering in the city: an annotated bibliography and review of the literature about human-plant interactions in urban ecosystems. Portland, OR: United States Department of Agriculture, Forest Service, Pacific Northwest Research Station General Technical Report PNW-GTR-849.

McLain, R., et al., 2012b. Producing edible landscapes in Seattle's urban forest. Urban Forestry and Urban Greening, 11 (2), 187-194.

Metcalf, S.S. and Widener, M.J., 2011. Growing Buffalo's capacity for local food: a systems framework for sustainable agriculture. Applied Geography, 31 (4), 1242-1251.

Moore, S., 2006. Forgotten roots of the green city: subsistence gardening in Columbus, Ohio. 1900 1940. Urban Geography, 27 (2), 174-192.

Morgan, G., Rocha, C., and Poynting, S., 2005. Grafting cultures: longing and belonging in immigrants' gardens and backyards in Fairfield. Journal of Intercultural Studies, 26 (1-2), 93-105.

Nordahl, D., 2009. Public produce: the new urban agriculture. Washington, DC: Island Press.

Philadelphia Orchard Project, 2007. Philadelphia Orchard Project home page [online]. Available from: www.phillyorchards.org [Accessed 16 September 2013].

Pincetl, S., 2010. From the sanitary city to the sustainable city: challenges to institutionalising biogenic (nature's services) infrastructure. Local Environments, 15 (1), 43-58.

Pincetl, S. and Gearin, E., 2005. The reinvention of public green space. Urban Geography, 26 (5), $365-384$

Poe, M.R., et al., 2013. Urban forest justice and the rights to wild foods, medicines, and materials in the city. Human Ecology [online]. Available from: http:/link.springer.com/article/10.1007/ s10745-013-9572-1 [Accessed 11 February 2013]. 
Portland Fruit Tree Project. 2010. Portland Fruit Tree Project [online]. Available from: www. portlandfruit.org [Accessed 16 September 2013].

Robbins, P., Emery, M., and Rice, J.L., 2008. Gathering in Thoreau's backyard: nontimber forest product harvesting as a practice. Area, 40 (2), 265-277.

Severson, K., 2009. Neighbor, can you spare a plum? The New York Times [online], 10 June. Available from: http://www.nytimes.com/2009/06/10/dining/10Fruit.html [Accessed 11 February 2013].

Turner, B., 2011. Embodied connections: sustainability, food systems and community gardens. Local Environment, 16 (6), 509-522.

Wehi, P.M. and Wehi, W.L., 2009. Traditional plant harvesting in contemporary fragmented and urban landscapes. Conservation Biology, 24 (2), 594-604.

Westphal, L.M., et al., 2008. Anglers' appraisals of the risks of eating sport-caught fish from industrial areas: lessons from Chicago's Calumet region. Human Ecology Review, 15 (1), 46-62.

Williams, R., 1973. The country and the city. New York: Oxford University Press. 